\title{
Interpretacje
}

\section{Edward Słoński, poeta I wojny}

Anna Nasiłowska

TEKSTY DRUGIE 2020, NR 5, S. 273-294

DOI: 10.18318/td.2020.5.17 | ORCID: 0000-00026171-5662

7 Trudno narzekać, że wiersze Edwarda Słońskiego 1 (1872-1926), przypominane i opisywane przez specjalistów ${ }^{1}$, cytowane nawet w pracach historycznych ${ }^{2}$, nie są pamiętane, choć w krótkim okresie 1914-1918 był to poeta pierwszoplanowy i jeden z najbardziej wyrazistych głosów. Po pierwsze, w ogóle mamy w Polsce problem z pamięcią o I wojnie światowej (mimo stulecia i stu konferencji z tej okazji). Po drugie, czas między stylistycznie mocno określoną Młodą Polską a wystąpieniem młodszych, z pierwszych lat drugiej niepodległości, rysuje się mało wyraźnie, kiedyś traktowany jako międzyepoka, w tej chwili - raczej fragment modernizmu, ale niezwracający uwagi jakością dokonań. Po trzecie, upływ czasu sprawia, że nie ma już świadków epoki, a społeczna pamięć odleglejszych zdarzeń zawsze ma tendencję do zatrzymywania głównych zarysów, a nawet stereotypów. To jednak taki czas, gdy wszystko było płynne, i poezja Słońskiego usiłowała tę płynność politycznego stanu

\section{Anna Nasiłowska \\ - profesor, historyk literatury, pracuje w Instytucie Badań Literackich PAN, czło- nek redakcji „Tekstów Drugich" od początku pisma. Prezeska Sto- warzyszenia Pisarzy Polskich od 2017 roku. Poetka, pisarka. W 2019 ukazała się jej Historia literatury polskiej. Kontakt: anna.nasilowska@ibl. waw.pl}

\footnotetext{
1 Kloch, Maciejewska, Romanowski.

2 Ostatnio Jesse Kauffman Iluzoryczne przymierze.
} 
uporządkować, nie sprowadzając się jednakże do dogmatów czy kilku nośnych a prostych haseł. Po czwarte, samo zjawisko nie rysuje się wyraźnie, gdy szukamy wyłącznie drukowanych zbiorów wierszy lub, w najlepszym razie, utworów w czasopismach, od czego zazwyczaj zaczyna historyk literatury. Czas był wyjątkowy, słowa ważkie i - wedle świadków epoki - trafiające do serc, poeta wymyślił więc dla nich dodatkowe sposoby funkcjonowania: na pocztówkach i w postaci pieśni do wykonywania z akompaniamentem fortepianu. W każdym szanującym się dworze, inteligenckim czy mieszczańskim domu było wtedy pianino i ktoś całkiem dobrze potrafiący grać. Pocztówka zaś to nie tylko tekst, ale i towarzysząca grafika, mały artefakt, przemawiający nie tylko za pomocą słów.

\section{Wiersze, które zrobiły karierę}

Twórczość poetycką i plastyczną łączył Słoński z działalnością polityczną w PPS, a także był czynnym dentystą, przyjmującym w centrum Warszawy. W 1912 roku, po wyjściu z więzienia przy Daniłowiczowskiej Edward Kozikowski miał dostarczyć gryps od kolegi z celi. Udał się w tym celu na ul. Jasną do gabinetu Słońskiego. Opowiada o tej wizycie tak:

Wyczekałem się długo, zanim przyszła na mnie kolej. Inaczej nie można było. Należało zachować wszelkie pozory, by nie budzić niepotrzebnych podejrzeń. Z powierzonej misji wywiązałem się bez zarzutu. Gdy uznałem ją za skończoną i objawiłem chęć opuszczenia gabinetu, Słoński kazał mi zająć miejsce w fotelu dentystycznym i szepnąwszy na ucho, że należy rolę odegrać do końca, przystąpił do oględzin mego uzębienia. I tak mimo woli stałem się nie tylko przyjacielem, ale i pacjentem Słońskiego. Brat łata o franciszkańskim sercu, wzdragający się z reguły przed przyjęciem od kolegów należnego mu honorarium lekarskiego. ${ }^{3}$

Jeszcze przed wybuchem wojny niezwykle popularny stał się wiersz Edwarda Słońskiego Ojczyzna z 1910 roku, powtórzony jako pocztówka w maju 1915, a więc jeszcze za czasów „rosyjskiej”Warszawy ${ }^{4}$. Poeta mówi w nim o ojczyźnie, która nie posiada granic, utraciła je wraz z bytem państwa. Wyrażał

3 E. Kozikowski, tamże, s. 98-99.

4 Pocztówka z wierszem Ojczyzna, data zezwolenia cenzury wojennej: 12 maja 1915, Nakład Chlebowski i Michałowski, „Świt”, Warszawa, druk: Wierzbicki i S-ka. 
także przywiązanie do krajobrazu, ale i wątpliwości, czy w ogóle da się rozsypane części posklejać w dawny kształt.

Rozsiadłaś się w obcych grodach

na świata wielkiej połowie -

o twoich głodach i chłodach

nikt nie wie, nikt się nie dowie.

Nikt się nie wzruszy do płaczu,

kiedy zaśpiewa kto czasem

o tym żołnierzu tułaczu,

co chodził borem i lasem.

Bo dzisiaj ty przebogata,

bezmiedzna i bezgraniczna,

ojczyzno z połowy świata,

wszak jesteś wielojęzyczna. ${ }^{5}$

Wacław Borowy, pisząc przed II wojną o tym wierszu, przywołał pierwodruk w warszawskim „Tygodniku Ilustrowanym” i stwierdził: „Ludziom późniejszych pokoleń trudno pewno będzie pojąć to wrażenie, jakie na nas wywierały te wiersze"6.

Drugim utworem Słońskiego, który wywarł ogromne wrażenie, jest $T a, c o$ nie zginęła. Wiersz opublikowany został po raz pierwszy w „Tygodniku Ilustrowanym" z 3 października 1914 roku, powstał więc w pierwszym okresie wojny. Tylko o tym utworze pisało wielu autorów, świadomych, jaką rolę odegrał.

Zdzisław Dębicki, redaktor „Tygodnika Ilustrowanego”, a także zwolennik narodowej demokracji pisał:

Wiersz, drukowany w „Tygodniku Illustrowanym”, obiegł z niesłychaną szybkością całą Polskę, przedarł się przez kordony graniczne i zasieki z drutu kolczastego, przedostał się do Galicji, do Legionów Piłsudskiego, poszedł w drugą stronę - na Ruś i Litwę, w trzecią do Wielkopolski,

5 E. Słoński Wybór wierszy..., S. 129, dalsze cytaty poezji Słońskiego na podstawie tego wydania, chyba że w przypisie zostało oznaczone inaczej.

6 W. Borowy Poezja Edwarda Słońskiego, w: tegoż Dziś i wczoraj, Towarzystwo Wydawnicze "Rój”, Warszawa 1934, s. 218. 
dotarł do Polaków ubranych w mundury rosyjskie, niemieckie i austriackie i przelewających swoją krew na wszystkich frontach - i wszędzie trafił prosto do serc. [...]

Był to rzadki wypadek niemal natychmiastowego spopularyzowania się utworu poetyckiego, dowód, że Słoński znalazł drogę do zbiorowego serca narodu i poruszył w nim wspólną wszystkim strunę miłości do Ojczyzny i wiary w to, że wstanie ona z krwi, przelanej w tej wojnie ludów, zapowiedzianej przez Mickiewicza. ${ }^{7}$

Jarosław Iwaszkiewicz wiele lat potem, $\mathrm{w}$ notach na marginesach antologii poezji polskiej Seweryna Pollaka, zanotował:

Wiersz Ta, co nie zginęła w pierwszym roku wojny zrobił zawrotną karierę. Gdyby istniała wtedy ochrona praw autorskich, przyniosłaby Słońskiemu majątek. A to był bardzo skromny człowieczek. ${ }^{8}$

Dębicki uważał, że napisanie tego utworu było najważniejszym tytułem do chwały jego autora:

Jeżeli jest prawda, że każdy poeta przychodzi na świat po to by spełnić włożoną na siebie misję, posłannictwa dokonać i odejść potem - to posłannictwem Słońskiego było niewątpliwie stać się poetą wojny i Legionów, do których w miarę rozwoju wypadków zbliżał się coraz bardziej ideowo.9

Tak samo oceniał ten utwór (i inne wiersze) Słońskiego z wczesnego okresu I wojny Wacław Borowy, przy okazji wyjaśniając nieco powody sukcesu i pokazując tło ówczesnego życia duchowego. Brakowało wyrazu dla skomplikowanych uczuć, poezja młodopolska nie mogła wiele zaoferować w momencie zwrotu politycznego, także proza nie przynosiła trafiających w sedno wypowiedzi. A był to czas niepokoju:

Na jego nagrobku można by napisać: poeta 1914-1915. A nie lada jaki to tytuł, nie lada jakie daty! Był to okres pamiętny, dla literatury polskiej

\footnotetext{
7 Z. Dębicki Portrety, seria II, Gebethner i Wolff, Warszawa 1920, s. 161-162.

8 J. Iwaszkiewicz Marginalia, Oficyna Wydawnicza Interim, Warszawa 1993, s. 12.

9 Z. Dębicki Portrety, s. 162-163.
} 
bardzo ciężki. Wielcy pisarze milczeli, a inni przeważnie zapełniali piśmiennictwo (jak to później dobitnie zobrazował Żeromski) „odruchowym, naśladowczym słowotokiem, stekiem bombastycznych wierszy i barokowej prozy", w których panowały czczość patosu bez wewnętrznego ognia. W czasach tak niebezpiecznej próby dla wielu „lir” skromna lirenka Słońskiego okazała się jedynym instrumentem poetyckim, który mógł wyrazić to, co czuła wielka część narodu. ${ }^{10}$

Edward Kozikowski o tym utworze, przeczytanym na łamach „Tygodnika Illustrowanego" napisał, że „zdobył od razu serca”"11.

Następnie, na początku 1915 roku, sympatyk PPS Słoński i zwolennik Narodowej Demokracji Zdzisław Dębicki wydali razem w Warszawie zbiorek wojennych wierszy. Każdy z nich zamieścił po dziesięć utworów, prezentowali się według alfabetu, czyli najpierw Dębicki. Otwierał jednak wiersz Edwarda Słońskiego, który dał tytuł całemu tomowi - Ta, co nie zginęła.

W publikowanej po śmierci poety w „Wiadomościach Literackich” Rozmowie o Edwardzie Stońskim znalazło się takie wspomnienie:

Ta, co nie zginęła? Ileż wspomnień wiąże się w mej głowie z tą książką! Pamiętam, byłem wówczas w Moskwie uczniem drugiej czy trzeciej klasy... W powietrzu było niewyraźnie, nikt jeszcze nic naprawdę nie wiedział, co ma myśleć i co ma czuć... i wtedy w tej atmosferze niepewności i lęku wyrastał ten wiersz. Kazano nam uczyć się go na pamięć i uczyliśmy się $\mathrm{z}$ radością. Powtarzaliśmy jak pacierz, wierzyliśmy na emigracji, zbiedzeni i wygnani, że „ta co nie zginęła, powstanie z naszej krwi” - jeżeli nie z krwi, to z łez przynajmniej. ${ }^{12}$

Autorem tego artykułu jest Eleuter (a więc Jarosław Iwaszkiewicz), zdaje się jednak, że przytacza on rozmowę swoich znajomych (pojawiają się jedynie imiona Andrzej i Kazimierz) - o czym świadczą wyraziście zarysowane postacie rozmówców i odniesienia do ich osobistych przeżyć. Kazimierz był już dorosły, podczas wojny przebywał na wsi, wspomina muzyczne wykonanie tego utworu podczas zaimprowizowanego koncertu:

10 W. Borowy Poezja Edwarda Słońskiego, s. 219.

11 E. Kozikowski Edward Słoński, w: Więcej prawdy niż plotki. Wspomnienia o pisarzach czasów minionych, PIW, Warszawa 1964, s. 101.

12 „Wiadomości Literackie” 1926 nr 39, s. 2. 
W słowach tej pieśni, podawanych z ust do ust, znajdowaliśmy wszyscy hasło i wskazówkę, zwracając twarz w stronę zachodu, gdzie lała się krew. W słowach tych odnaleźliśmy się i zrozumieli chwilę naszą i nasze zadania. $^{13}$

Wiersz Ta, co nie zginęła ukazał się na pocztówce, ozdobiony artystycznie wykonaną winietą, a więc był rozpowszechniany zgodnie z wolą tych, którzy kupili pocztówkę, poza tym Feliks Starczewski napisał do niego muzykę z przeznaczeniem do melodeklamacji lub śpiewu z towarzyszeniem fortepianu ${ }^{14}$. Do tego ostatniego faktu odnosi się drugi z rozmówców Eleutera. To ważne - choć nie całkiem dokładne świadectwo - że utwór z muzyką Starczewskiego był rzeczywiście wykonywany. Obaj uznają, że Słoński miał w tym czasie szczególny dar znajdowania właściwych akordów, uciszających dysonanse, szczęśliwa intuicja podpowiadała mu proste i trafne słowa. Zastanawiają się, czy nie uznać Słońskiego za "poetę pokolenia”.

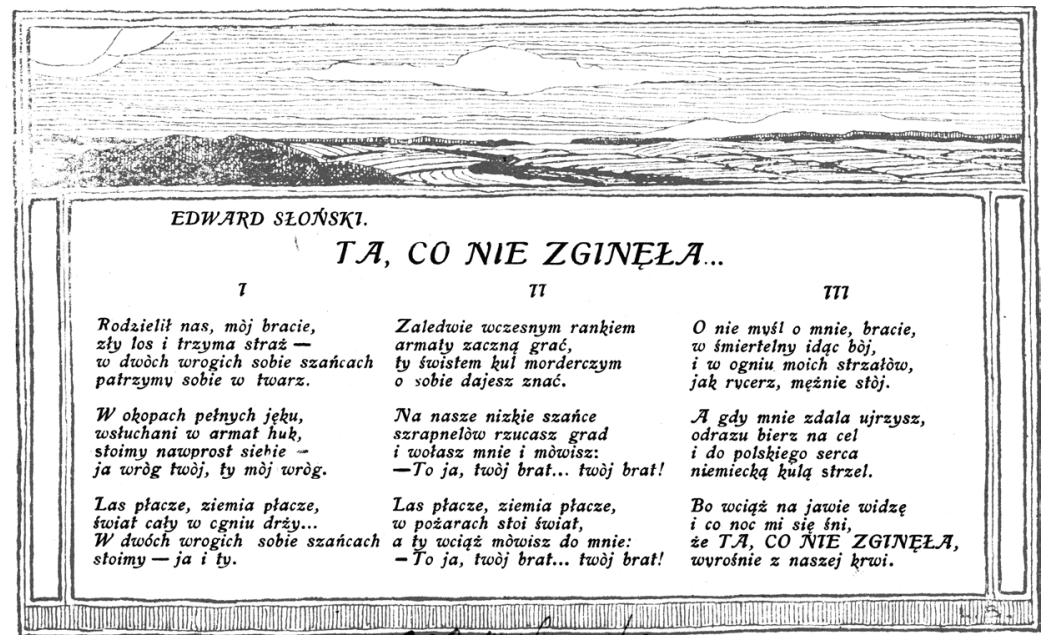

Pocztówka z wierszem Edwarda Słońskiego Ta, co nie zginęła, oryginalna kolorystyka szaroniebieska, ramka, zezwolenie na druk: 14 listopada 1914.

13 Tamże.

14 Biblioteka Narodowa w Warszawie, Muzykalia, III.64.233. 
Tak oto modernistyczna idea syntezy sztuk w latach I wojny zyskała nowe oblicze. Po wspólnym z Dębickim tomie Ta, co nie zginęła z 1915 roku w następnych latach, ze względu na wyczerpanie się nakładu, wiersze Edwarda Słońskiego zostały wydane osobno pod tym samym tytułem, a w roku 1916 ukazał się nowy zbiór Idzie żotnierz borem, lasem. W 1917 roku jeszcze ukazał się wybór wierszy Słońskiego, uzupełniony o nowe utwory, zatytułowany Jużja widzieli idąca... wiersze Edwarda Stońskiego o Polsce, o wojnie i żotnierzach. Początkowa współpraca Słońskiego i Dębickiego była niewątpliwie symbolicznym aktem zgody ponad podziałami. U Dębickiego pojawiają się jednak wyraźne akcenty antyaustriackie, u Słońskiego ich nie ma. Poza tym jeden wiersz Słońskiego i tak zdominował całość. Jest też spora różnica w funkcjonowaniu autorów, o ile w zbiorach Biblioteki Narodowej zachowała się jedna pocztówka z wierszem Dębickiego Pogrzeb, to utworów Słońskiego prezentowanych w ten sposób naliczyłam co najmniej siedemnaście. Możliwe, że ta dysproporcja ma tło finansowe; Słoński jako dentysta prawdopodobnie sam finansował druk kart, Dębicki utrzymywał się z pracy dziennikarza.

W wielu opracowaniach dotyczących Słońskiego pojawia się informacja o wstąpieniu poety do Legionów - jest ona jednak nieścisła. Natrafiamy na nią np. w biogramie antologii Andrzeja Romanowskiego Rozkwitały pąki biatych róż... ; ten sam autor w późniejszym haśle z Polskiego Słownika Biograficznego, po nowych badaniach, przyjął inną wersję: źródłem dotychczasowej była legenda rodzinna, jednak jak się wydaje Słoński, nie opuszczał w tym czasie Warszawy i prowadził gabinet. Dodajmy jeszcze, że Słoński, jako działacz PPS- $u$, należał do bezpośredniego politycznego zaplecza ruchu, z którym od początku się identyfikował. Legiony jako formacja nie odniosłyby sukcesu, gdyby nie fakt, że były jedynie organizacyjnie jednostką austriacką; dzięki polityce Piłsudskiego i z uwagi na szerokie zaplecze w Królestwie w postaci P.O.W. stały się zalążkiem polskiej armii. Słoński popierał te działania, od 1916 roku zaczęły pojawiać się w jego twórczości wiersze propagandowe, wspierające Piłsudskiego ${ }^{15}$. W wojsku był dopiero podczas wojny 1920 roku, służył w referacie prasowym, był prezesem Centralnego Komitetu Propagandy Związków Artystycznych.Zdjęcie w mundurze z „Tygodnika Ilustrowanego", publikowane z okazji śmierci poety, pochodzić musi z tego okresu, wskazuje na to analiza

15 Por. E. Słoński Do delegacji legionów, 6.11.1916, druk ulotny, Kraków 1916, w zbiorach Biblioteki Uniwersytetu Warszawskiego. Wiersz ten, noszący na sobie znamię pospieszności, przedrukowany w tomie Słońskiego Idzie żołnierz... Na ten sam dzień datowany jest list Józefa Piłsudskiego, przypominający się i odnawiający znajomość z rektorem Uniwersytetu Warszawskiego, wysłany z Krakowa. 
umundurowania. Dowództwo Komitetu Propagandy nosiło mundury oficerskie bez szarży, reszta - nie miała obowiązku noszenia munduru.

\section{Atmosfera wojny}

Wiersze i postawy wyrażone w tomie Ta, co nie zginęła wiążą się bezpośrednio z sytuacją w Warszawie w latach 1914-1915. Można o tym opowiedzieć, cytując relacje historyczne, jakie pozostawili Słoński i Dębicki, gdyż odnoszą się one i do faktów, i do panującej atmosfery, przynosząc świadectwo przeżyć, także takich, które nie pozostają na kartach historii politycznej. Zdzisław Dębicki w szkicu Warszawa w pierwszym roku wojny ${ }^{16}$ pisał, że z początku nie odczuwało się wyjątkowej sytuacji.

Lipiec [1914 roku - przyp. A.N.] zbliżał się ku końcowi. Jak zwykle o tej porze połowa Warszawy bawiła na letniskach lub u wód zagranicznych. Nawet redaktorzy naczelni dzienników, nawet kierownicy rubryk politycznych korzystali spokojnie z wczasów letnich, sądząc że „w razie czego” zawsze będzie dość czasu na powrót do opuszczonego stanowiska pracy.

$\mathrm{Ci}$, co pozostali w Warszawie, nie znali niepokojów. [...]

Nawet pogłoski o mobilizacji przyjęto z niedowierzaniem. Uspokajano się powtarzając słowa jakiegoś zdymisjonowanego generała rosyjskiego, który miał powiedzieć: „Dopóki nie zaczną się palić składy intendentury, bądźcie spokojni - wojny nie będzie. Z chwilą jednak, gdy przyjdzie wiadomość o pierwszym pożarze - miejcie się na baczności, bo to nieomylny znak wojny".

Gdy 26 lipca 1914 roku nad miastem rozszalała się burza i zapłonęły składy amunicji w Cytadeli, uznano to za złowieszczy znak. Niebawem dotarły wieści o bombardowaniu Kalisza. Zaczęto odczuwać strach, pojawiły się trudności transportu, odcięcie linii kolejowych. Pociągi kursowały tylko do Skierniewic. W mieście wybuchła panika bankowa, nagle wszyscy ruszyli po oszczędności i wstrzymano wypłaty. Potem zabrakło możliwości oświetlania ulic, gdyż nie było gazu z powodu braku węgla. Pojawiały się niemieckie samoloty, byli zabici, ruiny, zniszczenia. Już w sierpniu 1914 roku lipcowa beztroska ustąpiła innym uczuciom. Były one skomplikowane.

16 Z. Dębicki Warszawa w pierwszym rok wojny, "Kronika Warszawy” 1928 nr 7-9, dalsze cytaty $z$ tego artykułu. 
Odezwa Wielkiego Księcia Mikołaja Mikołajewicza z 14 sierpnia obiecywała zjednoczenie ziem polskich, samorząd, swobodę pod berłem rosyjskim. „Niechaj się zatrą granice rozcinające na części naród polski. Niech naród polski połączy się w jedno ciało pod berłem cesarza rosyjskiego. Pod berłem tym odrodzi się Polska, swobodna w swej wierze, języku i samorządzie..."17. Do Warszawy specjalna depesza dotarła nazajutrz, ale nie wzbudziła entuzjazmu. Dębicki pisał o tym tak:

Wśród łatwowiernych wywołała ona zachwyt i daleko idące nadzieje. Wśród powściągliwszych i lepiej znających wartość obietnic rosyjskich - duże zastrzeżenia. W rezultacie „depeszę wiernopoddańczą”, przesłaną na ręce W. Księcia podpisało tylko 68-miu Polaków. Nie więcej.

Depesza ta wysłana była w dniu 22 sierpnia, nazajutrz po zaćmieniu słońca, które to zjawisko wywołało duże wrażenie w mieście, potęgując grozę idących wydarzeń. Ludzie przesądni mogli byli snuć wnioski, jakie chcieli. Przede wszystkim jednak wysnuto wniosek niepowodzenia dla armii Samsonowa, na co też niedługo trzeba było czekać.

Tymczasem pogłębiły się braki w zaopatrzeniu. Zajęcie Lwowa przez wojska rosyjskie wznieciło obawy, a nie nadzieje, gdyż w Królestwie Lwów traktowany był jako oaza kultury polskiej.W tym samym czasie dotarły wiadomości o bezprawiu niemieckim w Belgii. Odczuwano ogromną sympatię dla tego kraju, spontanicznie powstał uroczysty adres do Belgów, przekazany za pośrednictwem Konsula, do którego dołączyli dość liczni wychowankowie Uniwersytetu w Louvain.

Inteligencja Warszawy dała jednak wówczas dowód hartu ducha i wytrwania. Dążeniem jej było utrzymanie życia potocznego w ramach zwykłych. Jakoż dzięki jej wysiłkowi nie tylko praca w szkołach nie uległa żadnej przerwie, lecz nawet doroczne posiedzenie Towarzystwa Naukowego odbyło się w dniu 26 listopada przy tak licznym udziale publiczności,jak gdyby nic temu nie przeszkadzało.

Panowała bieda, potrzebna była organizacja pomocy. Zajmowały się tym komitety społeczne, które rozdzielały dary z Petersburga, Moskwy, a nawet Irkucka: odzież, obuwie, żywność.

17 Cyt. za : J. Pajewski Odbudowa państwa polskiego 1914-1918, PWN, Warszawa 1980, s. 55. 
Życie polityczne u schyłku roku 1914 znamionują dwa fakty: dn. 4 listopada w dziennikach ukazuje się list otwarty niejakiego Witolda Gorczyńskiego, wyjaśniający pobudki, jakie go skłoniły do zabiegów o pozwolenie na formowanie legionów polskich, zaś 6-tego listopada zawiązuje się w Warszawie i wydaje motywowaną odezwę Komitet Narodowy Polski.

W tym czasie front bojowy, po wyplątaniu się Mackenzena z „worka" pod Łodzią, ustala się na linii rzek Bzury i Rawki izastyga na zimowe miesiące.

Warszawa staje się wskutek tego typowym miastem „na tyłach armii”, miastem zabawy i rozrywki dla oficerów. Złoto płynie w niej dość szerokim strumieniem, który jednak spływa przeważnie do kieszeni restauratorów i właścicieli kabaretów i kinematografów.

$[\ldots]$

Armie rosyjskie cofają się powoli, lecz cofają się stale, czyniąc coraz prawdopodobniejszym ustąpienie za Wisłę i dalej. Życie miasta nabiera cech niepokoju i niepewności.

Żadnego już nie czynią wrażenia zapowiedzi rosyjskie o ustanowieniu katedry literatury polskiej z językiem wykładowym polskim w Uniwersytecie Warszawskim, ani ogłoszona dn. 4 kwietnia (1915) ustawa o samorządzie miejskim dla Królestwa Polskiego, ani pogłoski o autonomii. Opinia publiczna interesuje się daleko więcej aeroplanami niemieckimi, które często zjawiają się nad miastem i rzucają na nie śmiercionośne pociski, od których giną ludzie na ulicach.

Wreszcie w lipcu położenie się wyjaśnia. Dnia 23-ciego tego miesiąca ogłoszone zostaje rozporządzenie „o przeniesieniu do guberni wewnętrznych zakładów i fabryk, mających znaczenie dla obrony państwowej".Jednocześnie ze szlaków, którymi ciągnie ustępująca z Królestwa armia, nadchodzą hiobowe wieści o niszczeniu pól, paleniu budynków i uprowadzaniu ludności.

W Warszawie rozpoczyna się prowadzona w pospiesznym tempie akcja ewakuacyjna. Ku dworcom wschodnim toczą się przez most Kierbedzia nieprzerwanym łańcuchem wozy i pojazdy wszelkiego rodzaju, a ludność miasta, tłumnie zgromadzona przy placu zamkowym, nie bez zadowolenia, choć niepewna swego jutra, patrzy na „wyprowadzanie się" władz i urzędów rosyjskich, świadoma, że oto odwraca się karta dziejów.

W tej sytuacji samorzutnie powołana zostaje straż obywatelska. O godzinie 6 rano 5 sierpnia 1915 roku miasto obudziła "potężna detonacja”. Wycofująca się armia rosyjska wysadziła wszystkie mosty na Wiśle. Zdzisław Dębicki, opowiadając o tym momencie, pamiętał o rocznicy: 
Tak zakończył się w stolicy Polski pierwszy rok wojny. W tym samym dniu i niemal o tej samej godzinie, kiedy przed laty ginął na szubienicy Romuald Traugutt.

Zapis historyczny Dębickiego jest precyzyjny, nie pomija także okoliczności trudnych do odtworzenia z dystansu: jak burza czy zaćmienie, skojarzenia z rocznicą stracenia Traugutta, wywołujące zawsze nieokreślony lęk przed przyszłością. Pomija tylko autor własną działalność, zapewne ze skromności czy wpojonego głęboko mniemania, że nie należy własnej osoby eksponować.

Żadne tradycyjne deklaracje stronnictw, prorosyjskie czy proniemieckie, nie miały sensu, czekać trzeba było na dalszy rozwój wydarzeń. Ciekawe światło na współpracę Dębickiego i Słońskiego, przedstawicieli odmiennych opcji, rzuca fragment ocalony przez historyka Janusza Pajewskiego ze spalonych w powstaniu warszawskim pamiętników Władysława Sobańskiego, kierownika Wydziału Zaopatrzenia Komitetu Obywatelskiego miasta Warszawy. Pisał on:

Praca w Komitecie [...] dała mi sposobność poznania i ocenienia wartości różnych sfer społecznych. Były to miodowe miesiące współżycia Polaków z rodzącą się państwowością polską. Powstające z konieczności wojennych różne Komitety Obywatelskie były znakomitą szkołą dla ludzi, których późniejsze wypadki wyniosły na kierownicze stanowiska w państwie. Zima roku 1914/1915 była nie tylko okresem gorączkowych nadziei, pracy i ofiar polskiego społeczeństwa, które instynktownie wyczuwało, że ta walka tytanów musi się odbić na losach Ojczyzny, ale bliskość frontu nadawała Warszawie nastrój jakiegoś dziwnego, lecz zdrowego napięcia. Każdy czuł, że choć polskiego wojska nie ma, ale też neutralni nie jesteśmy i być nie możemy, więc ci, których wojsko nie wchłonęło, czuli potrzebę oddania z siebie co jest w duszach i w sercach najlepszego w ofierze tym, którzy cierpią. Toteż orientacje były jeszcze wówczas przygłuszone hukiem armat znad Rawki i Bzury, a bliskość frontu pchała społeczeństwo do czynu i nie dawała czasu do sejmikowania. Nie chcę przez to powiedzieć, że wynik wojny, z kim współdziałać, było obojętne, ale okres ówczesny to była krwawa siejba, a plon i żniwa jeszcze daleki, więc Polacy, przynajmniej ci z zaboru rosyjskiego, gdy wojna rozwiązała nieco okowy, w których nas trzymano, pierwszym odruchem rzucili się do organizacji społecznych, tego zarodka gospodarki państwowej. ${ }^{18}$

18 J. Pajewski Odbudowa państwa polskiego..., s. 67-68, w przypisie wyjaśnienie autora: „Moje wypisy ze spalonych w czasie Powstania Warszawskiego Pamiętników Władysława Sobańskiego, obejmujących lata 1914-1918". 
Współpraca obu poetów przy wydaniu wspólnego tomu, znakomita oprawa graficzna, wymagająca włączenia artystów, wykorzystanie jako wstępu wiersza Słońskiego, zatarcie różnic orientacji politycznych - to właśnie skutek tej atmosfery spontanicznego szukania jak najszerszego porozumienia wokół spraw podstawowych i samoorganizacji społecznej w momencie głębokiej niepewności i oczekiwania na zmiany. W tym okresie różne stanowiska układają się wbrew tradycyjnym opcjom, według których Narodowa Demokracja wspierała orientację prorosyjską a lewica z Piłsudskim - państwa centralne.

To Słoński, „socjał z PPS-u”, szukał porozumienia z inteligencją rosyjską, co także nie powinno być interpretowane w ramach wielkiej polityki. Sprawa polska potrzebowała sojuszników, takie jest tło porozumienia i wymiany wierszy z Walerym Briusowem. Z kolei u Dębickiego trudno znaleźć dowody prorosyjskości, jako człowiek doświadczony w walce z caratem, represjonowany, zaznaczał przede wszystkim dystans. W początkach I wojny światowej każda z opcji była możliwa, byle dawała nadzieję.

Sytuacja w Warszawie zmieniła się z 4 na 5 sierpnia 1915 roku wraz z wkroczeniem wojsk niemieckich. Przede wszystkim pociągnęło to za sobą ogromne zniszczenia, nie tyle na skutek działań wojennych, co świadomych aktów armii rosyjskiej, która, nie chcąc pozostawić nieprzyjacielowi niczego wartościowego, niszczyła budynki i infrastrukturę. Ze względu na to, że w Warszawie wysadzone zostały mosty, przez kilka tygodni przeprawa przez Wisłę możliwa była tylko łodziami, potem - mostem pontonowym. W kolejnych numerach „Tygodnika Illustrowanego" obaj poeci zamieszczali teksty. Dębicki w numerze z 18 września 1915 roku opublikował artykuł Potrójny rys Polaka, zajmujący się różnymi typami postaw ukształtowanymi przez odmienne warunki kulturowo-polityczne w trzech zaborach, stawiający postulat „wyrobienia typu obywatela". W numerze z 9 października 1915 Edward Słoński zamieścił reportaż czy też - jak pisano wtedy - „obrazek” Modlin upadt. To relacja z wyprawy dorożką do Zakroczymia, następnie łodzią - na drugi brzeg Wisły.

Poeta przedrukował ją następnie w tomie Idzie żotnierz borem, lasem, gdzie otrzymała tytuł Modlin. Oto fragmenty:

Modlin upadł... Wszyscy myśleli, że Modlin jest twierdzą nie do zdobycia - i nagle Modlin upadł. Podziemne korytarze o betonowych sklepieniach nie wytrzymały huraganu wojny.

Dziś działa milczą. Śmiertelna cisza do stygnących luf przyciska swoje na wieki nieme usta. Podarte złomy betonowe na niskich fortach świadczą o sile ostatnich wybuchów. 
Tu była śmierć!

A dookoła leży straszna pustynia. Po wsiach zostały tylko okopcone kominy i żurawie studzienne po dworach, oplecione drutem kolczastym pnie drzew owocowych i popękane kafle pieców na pogorzeliskach.

W środku pustyni, przy ujściu Narwi do Wisły na malowniczym trójkącie leży Modlin.

$[\ldots]$

Po schodach, skleconych z desek, schodzimy z nasypu i po chwili znajdujemy się u przewozu. Żołnierz niemiecki pozwala trzem jeńcom przewieźć nas przez Wisłę.

Niebo szare iWisła szara, jak szynele jeńców, którzy milczą smutnie.

- Atkuda, panowie? - pyta jeden z nich.

- Z Warszawy...

- A ja z Besarabii... i ona zabrana... i cały świat...

Łódź zakołysała się pod naporem jego wiosła. ${ }^{19}$

Żołnierze rosyjscy budzą litość, to biedni ludzie, których wbrew ich woli los rzucił daleko, najpierw ubrał w rosyjskie mundury, a potem zrobił z nich jeńców. Największe wrażenie robi jednak informacja o pisanym po polsku liście wdeptanym w błoto, w którym jakaś kobieta pyta - pewnie męża - kiedy powróci, bo dobytek zmarniał. Czytelny jest tylko początek, resztę rozmazały deszcz, błoto i łzy. Słowa, porzucone, rozmywają się, nie ma tego, kto miał je czytać, nie wiadomo, czy kiedykolwiek powróci do domu.

„Strzelecka maciejówka”, wspomniana w reportażu, to dowód związków $\mathrm{z}$ ruchem strzeleckim.

\section{Edward Słoński i Walery Briusow}

Walerij Briusow (1873-1924), poeta, prozaik i tłumacz, jeden z najważniejszych przedstawicieli rosyjskiego symbolizmu i rosyjskiego „srebrnego wieku”, jako wrażliwy komentator poezji Puszkina, pisząc studium o Jeźdźcu miedzianym (1909), zetknął się także z poezją Mickiewicza, która bardzo go zainteresowała. Zanim w 1914 roku przybył do Warszawy jako dziennikarz, przedstawiciel rosyjskiego pisma „Russkije Wiedomosti”, napisał wiersz Do Polski (datowany 1 sierpnia 1914 roku, a więc przed oficjalną odezwą Wielkiego Księcia Mikołaja

19 E. Słoński Idzie żołnierz borem, lasem..., Nakładem Towarzystwa „Nowina", Warszawa 1916, S. 122-123. 
Mikołajewicza), przetłumaczony przez Edwarda Słońskiego, publikowany w polskiej prasie i na osobnej pocztówce. Dzięki ustaleniom prof. Jana Orłowskiego, który studiował dokumenty w archiwum pisarza w Moskwie, wiemy, że Briusow przybył do Warszawy 1 września 1914 roku, a już 6 września jako gościa specjalnego, autora wiersza Do Polski, podjęło go warszawskie Towarzystwo Literatów i Dziennikarzy, którego członkiem był Słoński. Z listów wiadomo także, że Briusow leczył zęby u Edwarda Słońskiego. Rosyjski poeta pisał o tym do żony: „Mój dentysta jest poetą i moim wielbicielem”20.

Słoński przekładał wiersze Briusowa na polski, napisał też do niego dwa sonety, a rosyjski poeta zrewanżował mu się wierszami rosyjskimi.

Walerij Briusow w czerwcu 1915 roku wyjechał z Warszawy w związku zjej zajęciem przez wojska niemieckie. Napisał osiem utworów związanych z Polską ${ }^{21}$.

Wiersz Briusowa Do Polski wydaje się nieśmiałym poparciem dążeń Polaków do samostanowienia, spełnieniem zawartych w nim deklaracji ideowych musiałaby stać się federacja z uwolnioną z ucisku carskiego Rosją, współgrać on też może z wizją słowianofilów. Widocznie jednak bardzo czekano na znak przychylności ze strony inteligencji rosyjskiej, także spoza oficjalnych kręgów władzy. W maju 1915 roku w wierszu jeszcze Polska jest! Wodpowiedzi Edwardowi Stońskiemu, napisanym w trakcie pobytu w Warszawie, rosyjski poeta wypowiedział się kolejny raz, dużo wyraźniej. Z tego utworu cytuję fragment w tłumaczeniu Tadeusza Łopalewskiego:

Tak, Polska jest! I któż temu zaprzeczy,

Że trwa wciąż naród jak w najlepsze wieki.

A choć mu groził gwałt silniejszej ręki

Już go potęga żadna nie zniweczy.

Wierzaj mi, bracie! Twoje męki wszystkie,

Gdyś dźwigał ciężar potrójnej obroży,

Kończą się dzisiaj, bo zwycięstwo bliskie

Korony szczątki w jedną całość złoży. ${ }^{22}$

20 Artykuł Jana Orłowskiego jest dostępny on-line: www.pisarze.pl/publicystyka/9377-jan-orlowski-walerij-briusow-w kregu-literatury-polskiej.html (27.11.2018).

Utwory te (tłumacze różni) można znaleźć w antologii: Dźwięki kuszonych oków. Polska w poezji rosyjskiej lat 1795-1917, red. B. Białokozowicz, LSW, Warszawa 1977, wiersze Briusowa na s. 201-206. Por. także: Poezja - mówię, Polska - myślę. Polska w poezji rosyjskiej XX wieku, red. W. Prichod'ko, A. Drawicz, Iskry, Warszawa 1973. 
W późniejszej, pochodzącej z 1917 roku broszurze Jakzakończyćwojnę Briusow napisał, że Rosjanie muszą pogodzić się z utratą „Kraju Przywiślańskiego”. Nie miał już wtedy kontaktów bezpośrednich z Polską, korespondencja zachowana w archiwum Briusowa w Rosyjskiej Bibliotece Państwowej w Moskwie urywa się wraz z wyjazdem z Warszawy, do którego zmusiło go przesunięcie się linii frontu ${ }^{23}$. W korespondencji Słońskiego z Briusowem jest list (odnaleziony przez prof. Jana Orłowskiego i cytowany w jego artykule), dotyczący tych utworów. Polski poeta napisał, że początkowo zamierzał napisać sonety po rosyjsku, przekonał się jednak, że jego język rosyjski zatracił poetycką zdolność. Po rosyjsku odpowiedział Briusowowi Leo Belmont. Jego wiersz Valeriju Briusovu drukowany był w piśmie „Izwiestia Literaturno-Chudożestwiennogo Kruga" w 1915 roku² $^{24}$.

\section{Pocztówki i piosenki}

Małgorzata Baranowska, która była znawczynią i kolekcjonerką pocztówek, pisała o pocztówkach okresu I wojny:

Tak jak się pocztówka uformowała na początku wieku, tak ruszyła na wielką wojnę. To była wojna pozycyjna [...]. Okopy pierwszej wojny roiły się zarówno od analfabetów, jak i poetów. W okopach siedzieli całymi miesiącami. [...] Poczta kwitła a wraz z nią pocztówka. Ciekawe, że to gatunek ulubiony zarówno przez cenzurę wojenną, bo propagandę wojenną można było na niej uprawiać, a skontrolować łatwo, jak i przez samych żołnierzy, bo ona najlepiej za ciebie wyrazi uczucia. ${ }^{25}$

Pocztówki tego okresu to szczególne zjawisko. Jeszcze w początkach wieku XX jako pocztówki wysyłano czasem prywatne zdjęcia, wywołane u fotografa i reprodukowane na grubym papierze, pisząc po obu stronach. W okresie pierwszej wojny pojawiło się bardzo dużo pocztówek informacyjnych, w których wykorzystywano zdjęcia dotyczące wydarzeń wojennych: na fotografiach widać zburzone budowle, jeńców prowadzonych do niewoli. Zwłaszcza za czasów władzy niemieckiej w Warszawie tego typu pocztówka stała się

Archiwum badał profesor Jan Orłowski: Walerij Briusow w kręgu literatury polskiej.

Za: W. Słobodnik, wstęp W. Briusow Poezje wybrane, PIW, Warszawa 1960. 
popularna ${ }^{26}$, oprócz innych z typowymi motywami, jak bukiety kwiatów czy aniołki służące do przesyłania powinszowań.

O ile pocztówki z tego okresu w zbiorach Małgorzaty Baranowskiej stanowią przykłady uroczego kiczu (którego nieświadomy surrealizm fascynował Małgorzatę) bądź propagandowe obrazy zniszczeń i tłumów jeńców idących do niewoli (posiadam w swoich zbiorach rodzinnych pocztówki austriackie z jeńcami serbskimi i rosyjskimi), to pocztówki do wierszy Edwarda Słońskiego są starannie zaprojektowane z wyraźną świadomością tworzenia obiektu artystycznego, zdobią je małe grafiki, dobrane do utworów, powstałe na tę okazję. Ramka, sposób prezentacji tekstu i towarzysząca tekstowi grafika tworzą starannie skomponowaną całość, nawet strona odwrotna, służąca do pisania adresu, tekstu i naklejania znaczka, jest często delikatnie zdobiona bordiurą ze stylizowanych roślinnych ornamentów, oczywiście dopasowaną do całości, tworzącą eleganckie wykończenie. Nie ma tu nic przypadkowego: czcionka, sposób łamania tekstu i dekoracja graficzna są harmonijne.

W małych grafikach, artystycznych winietach towarzyszących wierszom, podobnie jak w wielu ilustracjach do książek Słońskiego dla młodych czytelników (zwłaszcza Andrzeja Zarzyckiego, ale także w pracach anonimowych) widać wyraźne inspiracje drzeworytem japońskim. Pod koniec XIX wieku w sztuce europejskiej nastąpiło „odkrycie Japonii”, odbiło się ono także w sztuce polskiej. Był to ożywczy prąd estetyczny, jego efektem było docenienie grafiki, także użytkowej, zwrócenie uwagi na niewielkie formy i oszczędność form wyrazu artystycznego. W sztuce zen pejzaż jest bardzo wysoko ceniony, w XIV wieku utrwaliła się forma pionowego zwoju z grafiką pejzażową i poetyckim komentarzem. ${ }^{27}$

W Polsce inspiracje japońskie były bardzo silne. Dobrze znana jest działalność kolekcjonerska Feliksa Jasieńskiego, który zgromadził wspaniałą kolekcję. Początkowo przechowywał ją w Warszawie, ostatecznie, na skutek konfliktów, w 1901 roku przeniósł się do Krakowa i jego kolekcja jest w tej chwili prezentowana w Centrum Kultury i Techniki Japońskiej Manggha.

Bogate zbiory tego typu pocztówek w zbiorach Biblioteki im. Kierbedziów na Koszykowej. W moich zbiorach - pocztówki wysłane z Warszawy do mojego dziadka w początku 1918 roku: z jeńcami z Serbii (fotografia przedstawia rozbrojonych żołnierzy, pilnowanych przez niemieckiego wartownika z karabinem i lornetką oraz grupę jeńców z Rosji).

27 A. Kozyra Estetyka zen, Wydawnictwo Trio-Biblioteka Fundacji im Takashimy, Warszawa 2010, s. 108. 


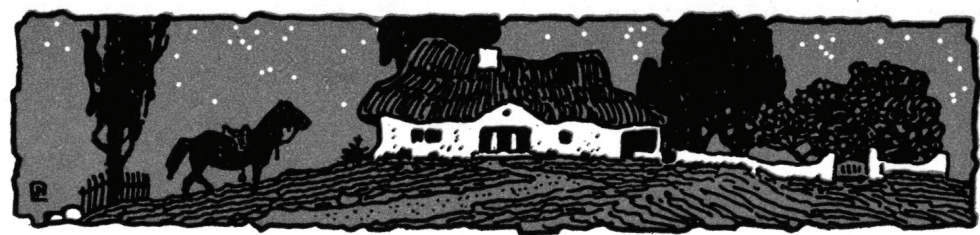

O, MÓJ ROZMARYNIE /

O, mój rozmarynie, o mój ty zielony, w mroku pod okienkiem zarżal konik wrony, jakiś cień $w$ księżycu $z$ nocy się wyłonił pode drzwiami ułan szabelką zadzwonił.

O, mój rozmarynie, ułan pode drzwiami zadzwonił szabelką, brzęknął ostrogami... - Otwórz, gospodarzu, do izby zaprowadź, w kącie u komina pozwól przenocować. Cztery doby zrzędu nie skłonilem glowy, wrony kon mój w polu pogubil podkowy... - Jakże mam otworzyć tobie, mily bracie, gdy ja sama jedna w tej bielonej chacie.

Ojca mi po nocy gdzieś uprowadzili, bratu sznur konopny na szyję włożyli.
Nie powiesz nikomu, mój kwiecie jedyny,
ze był u dziewczyny ułan od Beliny...

A drugiego brata, co sie ukryć zdolat,

ktosik od Krakowa po swojsku zawołał.

Odtąd sama jedna, mój mily żołnierzu,

siedzę czekająca w tym białym alkierzu,

siedzę czekająca co wieczór i rano

rychfo li rozmaryn zakwitnie pod ścianą. -

- Otwórz mi, dziewczyno, otwórz drzwi najszerzej,

pokłon ci od brata wiozę z Białowieży

i w ułańskiej kurtce głęboko schowany

list niewprawną ręką na siodle pisany.

- O, mój rozmarynie z pod bielonej ściany,

ułan list mi przywiózl na siodle pisany.

Ojca niema $w$ domu, brata niema w domu,

a ty, rozmarynie, nie powiesz nikomu.

6 września 1915.
EDWARD SEOŃSKI.

Warszawa 1916, Wiersz Edwarda Słońskiego z grafiką Eligiusza Niewiadomskiego

Inspiracje japońskie są niezależne od podziału na zabory i przenikają sztukę polską. Widoczne są zwłaszcza w grafice książkowej i w czasopismach literackich, wykorzystujących nieduże formy graficzne. Także w piśmie „Fala”.

Egzemplarz „Fali” z 5 maja 1906 roku dostępny jest w zbiorach Biblioteki Narodowej; Edward Słoński był redaktorem naczelnym pisma. Otwiera je jego wiersz Fala i dwa drzeworyty Andrzeja Zarzyckiego, w pewnym stopniu inspirowane klasycznym drzeworytem Hokusai Wielka fala w Kanagawie. Zarzycki odpowiadał pod względem plastycznym za całość numeru, ozdobionego drobniejszymi pracami graficznymi i jedną jego dużą grafiką, przestawiającą miejskie kamienice. Spośród autorów swoje teksty w „Fali” zamieścili Antoni Lange, Or-Ot, Andrzej Niemojewski i Wacław Rogowicz. Trudno powiedzieć, co było powodem poprzestania na jednym numerze, zapewne kłopoty finansowe.

Podobne inspiracje artystyczne dominowały w „Chimerze” Zenona Przesmyckiego (Miriama), z tym pismem współpracowali Feliks Jasieński jako krytyk sztuki oraz Ferdynand Ruszczyc jako grafik. Znawcą drzeworytu japońskiego był redaktor naczelny, w numerze trzecim pisma ukazało się jego studium Drzeworyt japoński ${ }^{\mathbf{2 8}}$, ilustrowane przykładami prac. Przesmycki powołuje się w nim na literaturę przedmiotu w trzech językach europej- 
skich (angielski, francuski, niemiecki), przedstawia rys historyczny zjawiska, rozwój techniki, szkoły i głównych twórców, podkreśla związek drzeworytu z ilustracją książkową. Przede wszystkim jednak pismo zamieszczało jako ilustracje dzieł literackich artystyczne winiety i drzeworyty polskich artystów; na przykład poemat Jana Kasprowicza Salve Regina opatrzony został znakomitymi pracami Edwarda Okunia (nr 4/5 z 1901 roku). Gdy „Chimera” przestała się ukazywać, wychodzący od 1908 roku w Warszawie, założony i redagowany przez Władysława Bukowińskiego (ps. Selim) miesięcznik literacki „Sfinks” kontynuował tę linię artystyczną, podobnie - czasopismo „Witeź”, redagowane przez Henryka Stanisława Pytlińskiego, z którym współpracował Słoński, zarówno jako autor grafik, jak i poeta. Współpracowali z nim także Zarzycki i inni artyści. Wszystkie numery miały bogatą szatę graficzną.

Najbardziej rewolucyjne estetycznie było podejście do kadru, w estetyce europejskiej główny obiekt umieszcza się w centrum kompozycji, czasami przesuwając go i równoważąc kompozycję innymi elementami, drugą zasadą jest prezentacja będącego tematem obiektu w całości. W estetyce japońskiej obie nie obowiązują, stosuje się cięcia, co jest odpowiednikiem niedopowiedzenia w literaturze. Taki sposób kadrowania widać na wielu grafikach pocztówkowych, ale także u Bogdana Nowakowskiego i Andrzeja Zarzyckiego w ilustracjach książek Słońskiego dla młodego czytelnika.

Wydaje się, że samodzielna aktywność Słońskiego jako grafika zamknęła się przed 1914 rokiem. Prace plastyczne samego Słońskiego, ozdabiające jego tomy z lat 1902-1904, noszą ślady japońskich inspiracji. Wybór poezji Słońskiego z 1911 roku, wydany przez Wydawnictwo Gebethner i Wolff, ukazał się z okładką zaprojektowaną przez Edwarda Trojanowskiego, ale wewnątrz, jako ilustracje poszczególnych części wyboru wierszy, zamieszczone zostały reprodukcje drzeworytów japońskich ${ }^{29}$. Jest to więc odwołanie bezpośrednie, a zapis niektórych nazwisk (Tatibana d'Osaka, d' z apostrofem i nazwa miasta) a także wprowadzenie akcentów sugeruje pośrednictwo francuskie. Nie byłoby to wyjątkowe, także Leopold Staff przekładał w epoce utwory w tomie Zfletni chińskiej za pośrednictwem francuskiego.

Grafiki do wierszy Słońskiego kryją kilka zagadek. Czy powstawały specjalnie, na zamówienie, do konkretnego wiersza? Czasami - z całą pewnością nie. Na przykład grafika, reprodukowana w 1915 roku wraz z utworem Tym,

29 Odpowiednia nota wyjaśnia: „Ozdoby w tekście podług drzeworytów japońskich: Shumboku (r. 1715), Inouma Yokusaí (r. 1876), Hokusai, Ooka, Oumpô i Sikiué Ountel (r. 1829), Korin (r. 1864), Yoshimoora Kastoumasa i Tatibana d'Osaka (r. 1755)". E. Słoński Wybór poezji, Warszawa 1911. 
którzy odeszli, przedstawiająca mężczyznę patrzącego na odległy krajobraz, wcześniej, w 1908 roku posłużyła w piśmie „Witeź” dwukrotnie - jako ilustracja do wiersza Marii Konopnickiej Pocałunek Roberta Emmeta (1908 nr 1) oraz w kolejnym, jako wprowadzenie graficzne do wiersza Władysława Orkana Naszła nas burza (1908 nr 2). Różnica jest tylko jedna, w „Witezi”, po lewej stronie znajduje się nieczytelna sygnatura autorska, na pocztówce - jej nie ma. Niektóre grafiki tworzone były jednak do konkretnych wierszy i sygnowane, choć nie zawsze efekt artystyczny był dobry. Przykład do porównań stanowi wiersz Na zgliszczach (ma też opracowanie muzyczne). Na pocztówce z tym wierszem Słońskiego, z rysunkiem Edwarda Trojanowskiego, widzimy po

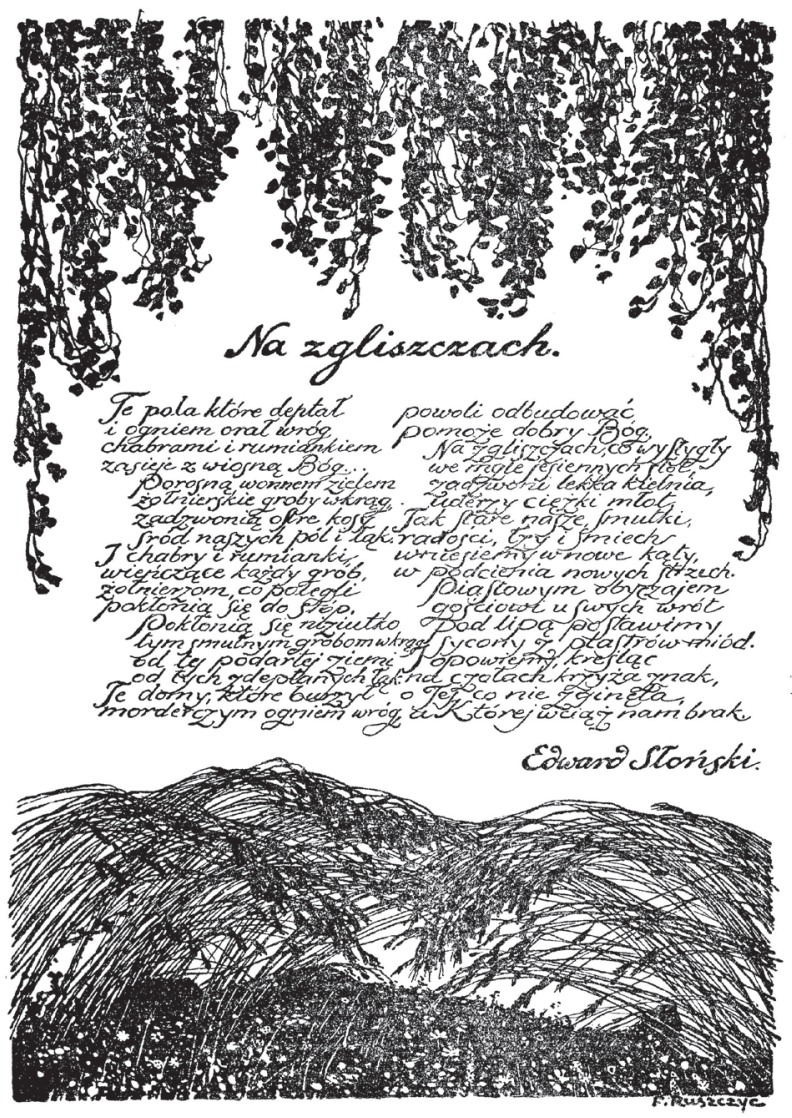

Pocztówka z wierszem Słońskiego, zezwolenie carskiej cenzury na druk: 7 listopada 1914, dostęp POLONA. 


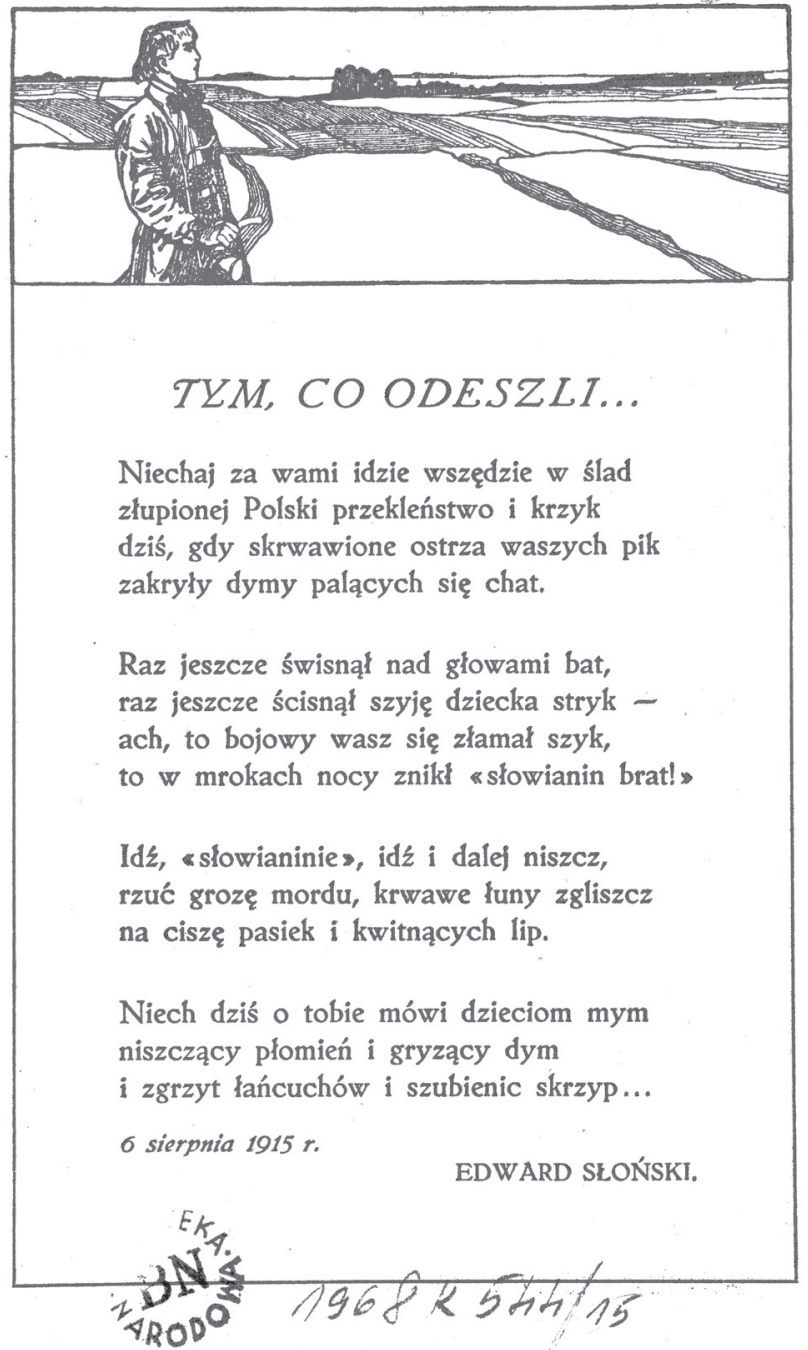

Pocztówka z wierszem E. Słońskiego Tym, co odeszli, oryginalna kolorystyka - sepia, kremowy papier, brak adnotacji o zezwoleniu rosyjskiej cenzury, datowanie po sierpniu 1915

prostu tlące się jeszcze zgliszcza miasta. Wspaniała dekoracja rysunkowa Ferdynanda Ruszczyca, wykorzystana w tomiku dwóch autorów Ta, co nie zginęła, połączona z kaligrafią idzie w odmiennym kierunku, ukazuje bogatą roślinność, zapowiada odrodzenie biologiczne. W tekście poetyckim zaznaczone 
są oba kierunki. Ale i tu jest niespodzianka, ta sama dekoracja Ruszczyca (z którym Słoński się przyjaźnił) wykorzystana została na pocztówce z innym wierszem $C z y$ ty wyrośniesz ${ }^{30}$. W obu wypadkach rysunek proponuje uspokojenie, przeniesienie afektu i sublimację. Podobny efekt dają spokojne pejzaże, wykorzystane w wierszach Ojczyzna, Tym, którzy odeszli i Ta, co nie zginęła to przeniesienie wzroku ku dalekiemu, otwartemu horyzontowi.

Artystyczne ujęcia zastosowane w latach 1914-1915 czerpią z dorobku lat wcześniejszych, traktując ilustracje jako otwarte archiwum, nie w pełni autorskie, choć czasami sygnowane znakomitymi nazwiskami. W latach następnych Słoński zacieśnił współpracę z konkretnymi plastykami, zwłaszcza przy książkach dla dzieci. Znakomite do powieści Słońskiego dla młodych ilustracje stworzyli Bogdan Nowakowski, Andrzej Zarzycki i Eligiusz Niewiadomski. Tak, ten sam. Projektował np. pocztówki z tekstem Słońskiego O mój rozmarynie (a więc piosenka legionowa!) i do wiersza Wiosna, następnie - ilustracje do powieści Na progu Polski (1921) o Lwowie. Niewiadomski był też autorem Ex Librisu Zdzisława Dębickiego i jednym z autorów publikujących w „Witezi”. Dla obu poetów śmiertelne strzały do Prezydenta Narutowicza oddane przez malarza musiały być szokiem. Znali - człowieka utalentowanego.

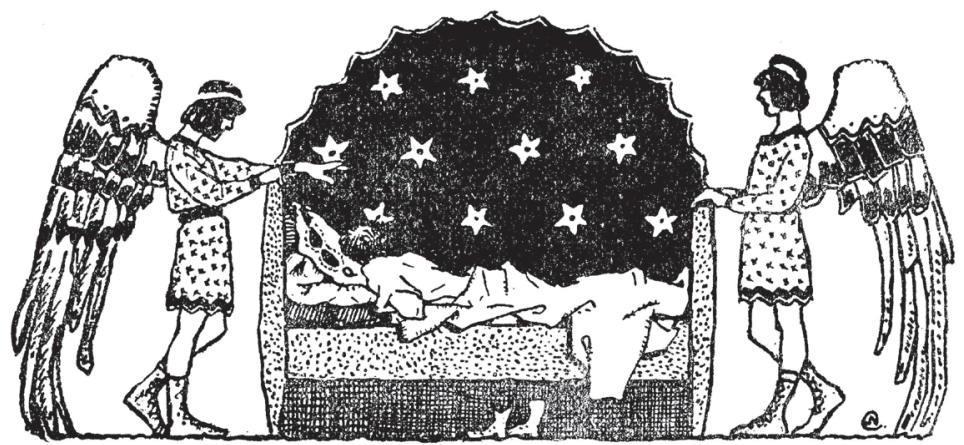

Eligiusz Niewiadomski, ilustracja do powieści Edwarda Słońskiego Na progu Polski.

Dla tego pokolenia szok wolności oznaczał rozpad budowanej z dużym trudem, przez lata wspólnoty, wybuch antagonizmów, a także zastąpienie

30 Warszawa 1915, druk: Chlebowski i Michałowski, „Świt”, Warszawa, zakład graficzny Wierzbicki iska. 
bardzo subtelnego języka artystycznego znacznie prostszym stylem. Zamiast fantazyjnej czcionki - antykwa, zamiast dekoracji graficznych, sięgających po motywy przyrodnicze - motywy mitologiczne lub formy futurystyczne, zamiast sublimacji - emocje.

\section{Abstract}

\section{Anna Nasiłowska}

THE INSTITUTE OF LITERARY RESEARCH OF THE POLISH ACADEMY OF SCIENCES (WARSAW)

\section{Edward Słoński, Poet of World War I}

Nasiłowska presents the work of Edward Słoński, author of two outstandingly popular poems. Słoński, who ran a dentist's clinic in Warsaw at the time, wrote on postcards, adding sophisticated graphic art by different artists. In the early twentieth century he had been a graphic artist as well; he had also been editor of the short-lived journal Fala, and he collaborated with other journals. His own artwork and the work of other graphic artists draw on Japanese art, which was in vogue at the time. Słoński's works have also been set to music and performed as songs. His poems deal with experiences from the beginning of the war. Słoński also worked with Valery Bryusov, who was staying in Warsaw as a Russian press correspondent at the beginning of the war.

\section{Keywords}

World War I, Edward Słoński, Japanese woodcut, Młoda Polska, Young Poland, synthesis of the arts, poetry and music, poetry and graphic art 